\title{
Serum electrolytes and renal histology of Wistar rats treated with seed extract of Citrullus lanatus
}

\author{
Simon Irikefe OVUAKPORAYE ${ }^{1 *}$, Taniyohwo Mamerhi ENAOHWO², Joseph \\ Chukwufumnaya MORDI ${ }^{3}$ and Alex Obidike NAIHO ${ }^{1}$ \\ ${ }^{1}$ Department of Human Physiology, Faculty of Basic Medical Sciences; ${ }^{2}$ Department of Human Anatomy and Cell \\ Biology; ${ }^{3}$ Department of Medical Biochemistry Delta State University, P.M.B. 1, Abraka. Nigeria. \\ Received $27^{\text {th }}$ January 2020; Accepted $28^{\text {th }}$ February 2020
}

\begin{abstract}
Medicinal plants are frequently used in healthcare delivery in Sub-Saharan Africa and other parts of the world because of their bioactive compounds, thus accounting for about $80 \%$ of African medicine. The kidneys are involved in one of the body's most important homeostasis. This study evaluated the effects of Citrullus lanatus fruit juice on serum electrolytes and histology of the kidney in Wistar rats. Seventy (70) male Wistar rats were used for the study and categorized into four groups ( $\mathrm{n}=9$ ). Group 1 (control group) were fed with growers mash and water only. Animals in groups 2, 3 and 4 were given $2.5 \mathrm{mg} / \mathrm{kg}, 5 \mathrm{ml} / \mathrm{kg}$ and $10 \mathrm{ml} / \mathrm{kg}$ of the extract along with growers mash respectively. Findings showed a dose dependent increase in bodyweight (expressed in percentage) in all groups. There was no significant difference $(\mathrm{P}>0.05)$ in serum $\mathrm{Na}^{+}, \mathrm{Cl}^{-}$, creatinine, $\mathrm{HCO}_{3}$ and urea in animals given watermelon seed extract $(81.69 \pm 13.08 ; 85.22 \pm 8.25 ; 4.80 \pm 0.04 ; 27.78 \pm 5.48 ; 7.05 \pm 0.25)$ when compared with control group $(102.62 \pm 7.40 ; 86.78 \pm 7.61 ; 26.90 \pm 2.46 ; 7.52 \pm 0.59 ; 28.26 \pm 5.24)$. However, there was significant increase in serum $\mathrm{K}^{+}$level in animals given watermelon seed extract of $2.5 \mathrm{ml} / \mathrm{kg}$ group $(3.77 \pm 0.12)$ when compared with control group (3.49 \pm 0.08 ). In addition, significant increase was observed in urea level in $2.5 \mathrm{ml} / \mathrm{kg}$ experimental animals $(49.27 \pm 7.38)$ when compared with control (28.26 \pm 5.24$)$. In conclusion, administration of Citrullus lanatus seed extract did not affect serum electrolytes level, except serum potassium, however, it caused an increase in the bodyweight of Wistar rats but show no significant alteration in histological architecture of the kidney when compared to control.
\end{abstract}

Keywords: Serum electrolyte; Renal histology; Citrullus lanatus

\section{INTRODUCTION}

It has been reported that infectious diseases account for one-half of all deaths in the tropical countries [1]. As a result, the population in most continents have policies and imbibed infusions of indigenous plants dating back to prehistory for health purposes and is still in use today [2,3]. Plant medicine (phytomedicine) has been used in healthcare delivery in most African countries and the rest of the globe [4]. Effective health cannot be attained in Africa unless conventional medicine is complemented with traditional one [4]. At least $80 \%$ of Africans depend on plant medicine for their healthcare [2]. Citrullus lanatus (watermelon) produces a fruit that is about $93 \%$ water, hence the name "water" melon. The "melon" part came from

\footnotetext{
*Correspondence. E-mail: simonovuakpo2006@yahoo.com Tel: +234-8037780937.

ISSN 0189-8442

(cc) BY-Nc 2020 Published by Faculty of Pharmaceutical Sciences, University of Jos, Nigeria. Under Creative Commons Attribution-NonCommercial 4.0 International License. https://creativecommons.org/licenses/by-nc/4.0/
} 
the fact that the fruit is large and round and has a sweet, pulpy flesh. Watermelon is thought to have originated in southern Africa because it is found growing wild throughout the area, and reaches maximum diversity of forms there. It has been cultivated in Africa for over 4,000 years. Citrullus lanatus was brought to America by the Spanish and it quickly became a very popular crop [5]. They only chew the pulp and enjoy the juice. More also, Watermelon is seen as a common fruit that has led to it being wasted on daily basis as it is a perishable fruit and there is poor storage culture.

This study determines the effects of the seed extract of Citrullus lanatus on the kidney histology and serum electrolytes of Wistar rats. Specifically, sodium, bicarbonate, creatinine, potassium, chloride, in the intracellular fluid (ICF) and the extracellular fluid (ECF). Watermelon (Citrullus lanatus) seeds are most times thrown away while the fruit is eaten [6]. Thereby resulting in the vital parts of the fruit being an agricultural waste. Therefore, this study sought to create awareness on the positive effects and negative effects of the consumption of the seeds of Citrullus lanatus.

\section{EXPERIMENTAL}

Materials. The plant used in this study is Citrullus lanatus seed while the animals used are specifically adult male Wistar rats. Thirty rats were bought, eight died and twenty-two were used for sample collection. Other materials used in this study include; wooden cages with iron netting, sawdust (litter), animal feed (growers mash) and water, laboratory coat and gloves, dissecting set and dissecting board, measuring cylinder and plastic specimen bottle, weighing balance, water bath, desiccator, syringes, sample bottles, $10 \%$ normal saline, cotton wool, glass slides and slide rack, hot plate, feeding trough, wire net cage, needles and syringes (2 $\mathrm{m} 1,5 \mathrm{~m} 1$ ), face masks, electronic weighing balance, sensitive electrical weighing balance (model JA 2003), sample containers, bucket centrifuge, UV-vis spectrophotometer (model 722n), electrical thermostatic water bath boiler (Model Dk 420), micropipettes (REMI) 100-1 0001, incubator, $\mathrm{pH}$ meter, mortar and pestle, cotton filter, 10 litres can, plastic bucket with cover, rotary evaporator, oven, beaker $(20 \mathrm{~m} 1,50 \mathrm{ml}, 500 \mathrm{~m} 1)$, bucket centrifuge (model 800E).

Animal grouping. The study consisted of thirty (30) male Wistar rats that were randomly selected into four groups,

GROUP 1: Control group not treated $(\mathrm{n}=5)$,

GROUP 2: Low dose $(2.5 \mathrm{ml} / \mathrm{kg})$,

GROUP 3: Medium dose (5 ml/kg),

GROUP 4: High dose $(10 \mathrm{ml} / \mathrm{kg})$.

The rats were weighed using an electronic balance. The weight of the male rats before the commencement of the experiment ranged from $150 \mathrm{~g}$ to $200 \mathrm{~g}$. The bodyweight of the Wistar rats was assessed weekly.

Plant collection, identification and preparation. Fruit is a subglobose berry 1.5$20 \mathrm{~cm}$ in diameter, greenish molted with darker green, when ripe its pulp is red. It is many seeded; seeds are dull brown, ovate and flattened $9-12 \times 5-7 \mathrm{~mm}$. The fresh fruit of Citrullus lanatus was obtained from Abraka central market, identified in line with the above standard [5] and washed with clean water. The seeds were removed from the red fleshy part. The seeds were sun-dried for three days and grounded to powder form. Thereafter, $50 \mathrm{~g}$ of the powder was soaked in $990 \mathrm{ml}$ of ethanol and allowed to stand for 24 h. Subsequently, the mixture was filtered to separate the filtrate from the residue with a white handkerchief. The filtrate is concentrated in an extractor machine. The concentrate is placed inside the heating mantle of the fume cupboard of the extracting machine to evaporate the ethanol and forming a sticky extract that is stored in the refrigerator. $1 \mathrm{~g}$ of each extract was measured and dissolved in $10 \mathrm{ml}$ of distilled water. This 
is then administered to the rats at a dose of $500 \mathrm{mg} / \mathrm{kg}$.

Animal procurement and care. Thirty (30) adult male albino Wistar rats obtained from the animal house of the Faculty of Basic Medical Sciences, College of Health Sciences, Delta State University Abraka, weighing between $150 \mathrm{~g}$ - 200g were used for the study. The Wistar rats were housed with well- ventilated animal unit provided by the College, $\left(28 \pm 2^{\circ} \mathrm{C}\right.$, relative humidity $60-70$ $\%, 12 \mathrm{hr}$ light/dark cycle) [7]. They received humane care in compliance with the ethical guide approved by the College of Health Sciences, Delta State University, Abraka, Delta State, Nigeria by following the National Institute of Health $(\mathrm{NIH})$ guidelines for the care and use of laboratory animals. During the entire period of study the animals were fed with standard grower mash diet and water ad libitum, in a standard wire meshed wooden cages for 7 days prior to commencement of the experiment. [Composition of the grower's marsh: Protein $-19.0 \%$ Fat $-2.85 \%$ Fibre $6.00 \%$ Calcium - $1.00 \%$ Available phosphate $-0.45 \%$ Energy -2875 KGC (Animal Care Services Konsult (NIG) Ltd., Asaba, Delta State)].

Sample collection. At the end of the 28 days treatment with Citrullus lanatus seed extract, the rats fasted overnight and at the time of sacrifice, the weight was taken. At the end of treatment, animals were anesthetized by placing them in desiccator already containing cotton wool soaked with chloroform. As soon as the animals were unconscious, they were laid supine on a dissecting board and a laparotomy was carried out and the blood samples were collected from the inferior vena cava with the aid of $5-\mathrm{m} 1$ syringes, into lithium heparin bottles. The tubes then centrifuged at $4000 \mathrm{rpm}$ for 10minutes to obtain serum for biochemical analysis using spectrophotometer methods with reagent kits. A portion of the kidney was fixed (suspended) in cold $10 \%$ formal saline for histological studies.

Determination of serum sodium $\left(\mathrm{Na}^{+}\right)$, potassium $\left(\mathrm{K}^{+}\right)$and chloride $\left(\mathrm{Cl}^{-}\right)$. The different biochemical methods for determination of $\mathrm{Na}^{+}, \mathrm{K}^{+}$and $\mathrm{Cl}^{-}$using standard biochemical procedures and principles were employed. Sodium was determined based on method of Maruna [8]. Sodium was precipitated as the triple salt, sodium magnesium uranyl acetate, with the excess uranium being reacted with ferrocyanide to produce chromophore whose absorbance varies indirectly with the concentration of sodium in the test sample. Potassium was determined based on method of Terri and Sesin [9]. The amount of potassium $\left(\mathrm{K}^{+}\right)$was determined by using sodium tetraphenylboron, a specifically prepared mixture to produce a colloidal suspension. Chloride was estimated using the method described by Skeggs and Hochestrasser [10].

Determination of serum urea and creatinine. The methods as described by Tobacco [11] and Heinegard and Tiderstom [12] were used in the biochemical assay for serum urea and creatinine respectively. Standard procedure for serum urea and creatinine determination was followed and the absorbance was read and recorded for all test tubes

Ethical consideration. The ethical code of conduct governing experimental life animals was strictly observed and adhered to as stipulated by Ward and Elsea [13]. For use and care of laboratory animals, all NIH Guide was employed. Approval was sought from the research, ethics and grant committee of the Faculty of Basic Medical Sciences, Delta State University, Abraka (REC/FBMS/DELSU/17/14)

Statistical analysis. The results were expressed as Mean \pm SEM (Standard Error of the Mean). Statistical comparisons were 
performed by One-Way Analysis of Variance (ANOVA) followed by Fisher's Least Significant Difference (LSD). The SPSS software (version 21.0) was used in the Statistical analysis using the Multiple Comparisons Test. A P-value of less than 0.05 $(\mathrm{p}<0.05)$ was considered significant while a P. value greater than $0.05(\mathrm{p}>0.05)$ was considered to be statistically non-significant.

\section{RESULTS}

Result from this study (Fig. 1) shows a decrease in bodyweight of animals fed with watermelon seed extract when compared with the control rats and the decrease was lowest in medium dose, low dose and high dose. Figure 2 showed no significant difference $(\mathrm{P}>0.05)$ in plasma sodium level of animals administered with watermelon seed extract across all doses $(2.5 \mathrm{mg} / \mathrm{kg}, 5 \mathrm{mg} / \mathrm{kg}$ and 10 $\mathrm{mg} / \mathrm{kg}$ ) when compared with the control group. Results from this study (Fig. 3) showed a significant increase $\left(\mathrm{P}<0.05^{\mathrm{a}}\right)$ in plasma potassium level of animals administered with low dose $(2.5 \mathrm{mg} / \mathrm{kg})$ watermelon seed extract when compared with the control group. However, no significant difference was observed in experimental groups administered with medium dose (5 $\mathrm{mg} / \mathrm{kg}$ ) and high dose $10 \mathrm{mg} / \mathrm{kg}$ ) of watermelon seed extract when compared with control group. Figure 4 showed no significant difference $\left(\mathrm{P}>0.05^{\mathrm{ns}}\right)$ in plasma chloride level of animals administered with watermelon seed extract across all doses $(2.5 \mathrm{mg} / \mathrm{kg}$,
$5 \mathrm{mg} / \mathrm{kg}$ and $10 \mathrm{mg} / \mathrm{kg}$ ) when compared with control group. Similarly, in Figure 5, there was no significant difference $\left(\mathrm{P}>0.05^{\mathrm{ns}}\right)$ in plasma bicarbonate level of animals administered with watermelon seed extract across all doses $(2.5 \mathrm{mg} / \mathrm{kg}, 5 \mathrm{mg} / \mathrm{kg}$ and 10 $\mathrm{mg} / \mathrm{kg}$ ) when compared with control group. Figure 6 revealed significant increase $\left(\mathrm{P}<0.05^{\mathrm{a}}\right)$ in plasma urea level in animals administered with low dose $(2.5 \mathrm{mg} / \mathrm{kg})$ of watermelon seed extract while medium and high doses show significant differences when compared with the control group. Result from plasma creatinine determination (Fig. 7) however showed no significant increase $\left(\mathrm{P}<0.05^{\mathrm{a}}\right)$ in animals administered with watermelon seed extract across all doses $(* 2.5 \mathrm{p}-\mathrm{mg} / \mathrm{kg}, 5 \mathrm{mg} / \mathrm{kg}$ and $10 \mathrm{mg} / \mathrm{kg}$ ) when compared with the control group. The Results from histomicrograph of the kidney (Fig. 8) showed no observable histological alterations were seen in experimental rats administered with Citrullus lanatus extract when compared with the control rats. Sections of the kidney show a cuticle, cortex and medulla. The cortex contains several variably sized renal capsules. The epithelial lining varies starting from squamous, through cuboidal to columnar. Blood vessels, specifically capillaries are seen in the- loose connective tissue of the renal parenchyma. The hilum of the kidney is lined by transitional epithelium.

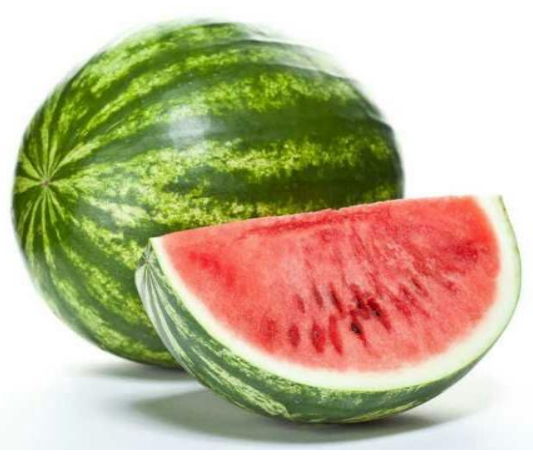




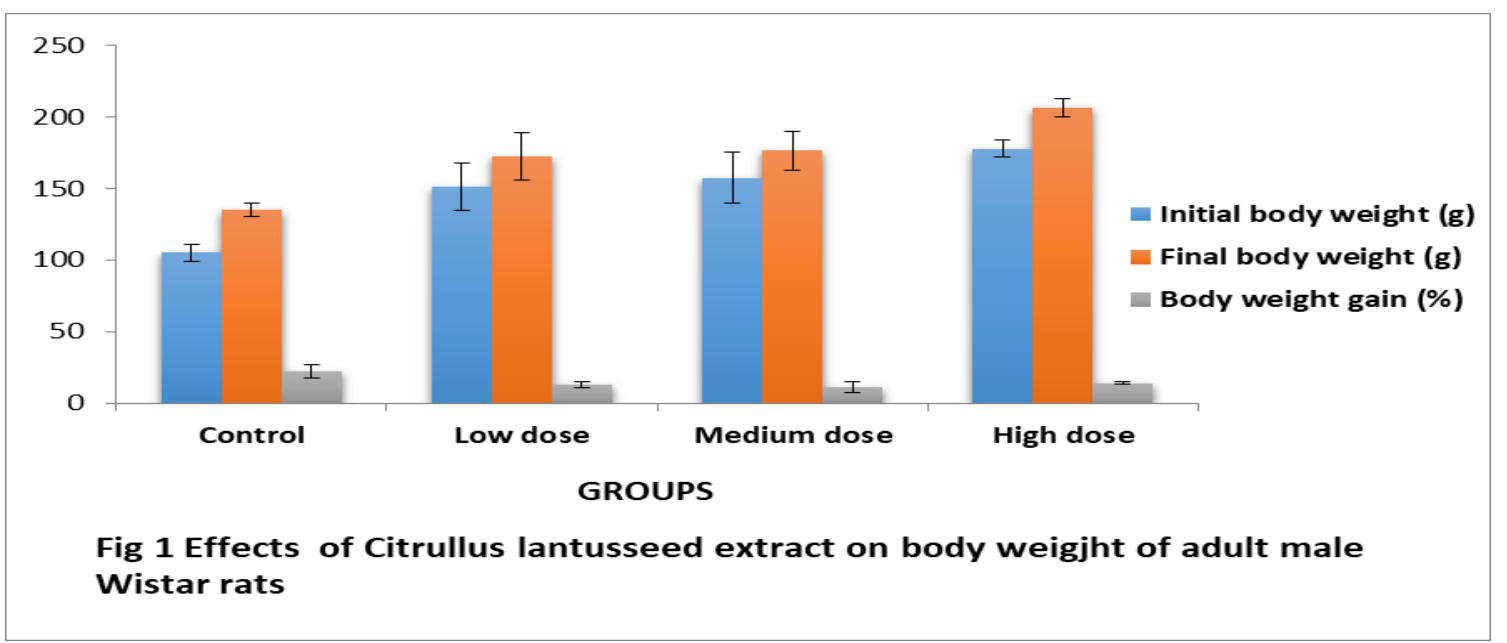

Figure 1 Effect of Citrullus lanatus seed extract on bodyweight of male Wistar rats.

Values are expressed as mean \pm Standard error of mean (S.E.M), $n=4 . P>0.05^{n s}$ : No Significant, P<0.05a: Significant increase when compared control group. $P<0.05^{b}$ : Significant decrease when compared control group.

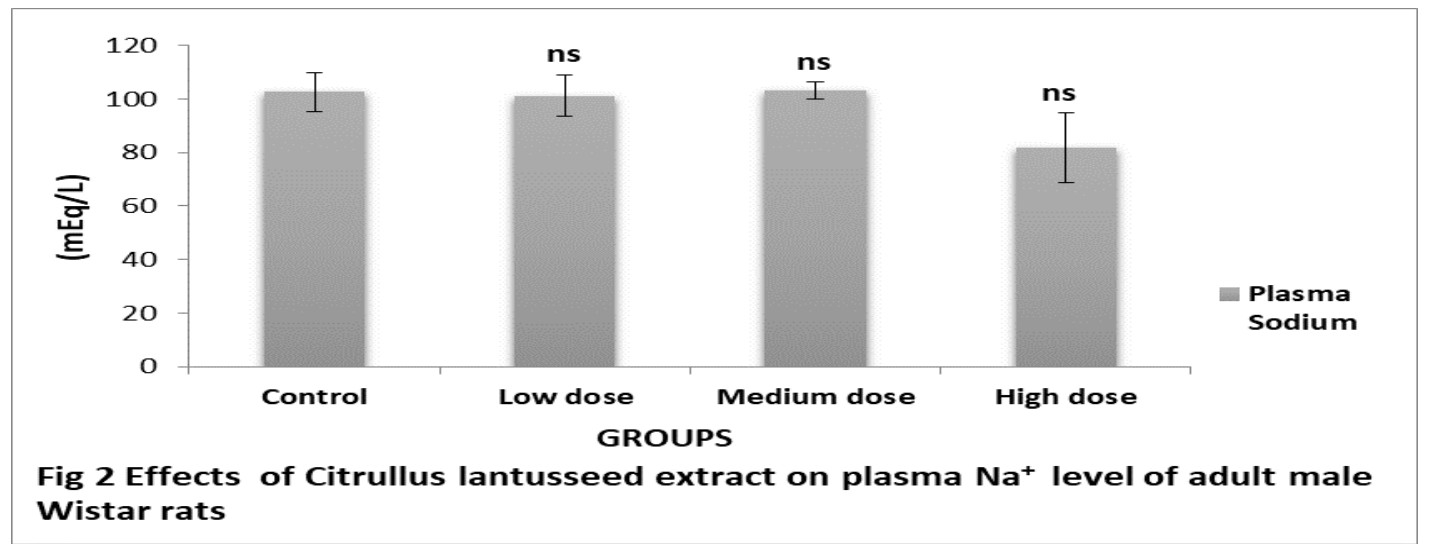

Figure 2. Effect of Citrullus lanatus seed extract on plasma sodium level of male Wistar rats.

Values are expressed as mean \pm Standard error of mean (S.E.M), $n=4 . P>0.05^{n s}$ : No Significant, $P<0.05^{a}$ :

Significant increase when compared control group. $P<0.05^{b}$ : Significant decrease when compared control group.

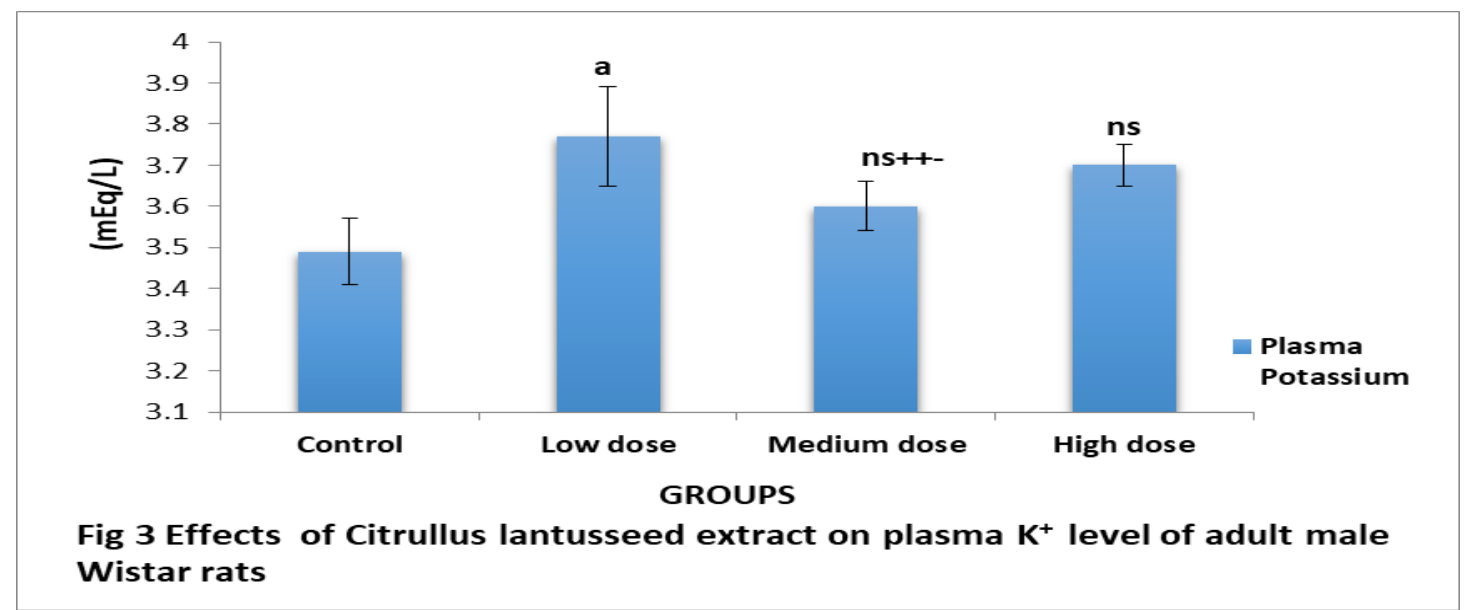

Figure 3. Effect of Citrullus lanatus seed extract on plasma potassium level of male Wistar rats.

Values are expressed as mean \pm Standard error of mean (S.E.M), $n=4 . P>0.05^{n s}$ : No Significant, $P<0.05^{a}$ :

Significant increase when compared control group. $P<0.05^{b}$ : Significant decrease when compared control group. 
S.I. Ovuakporaye et al. / J. Pharmacy \& Bioresources 17(1), 66-74 (2020)

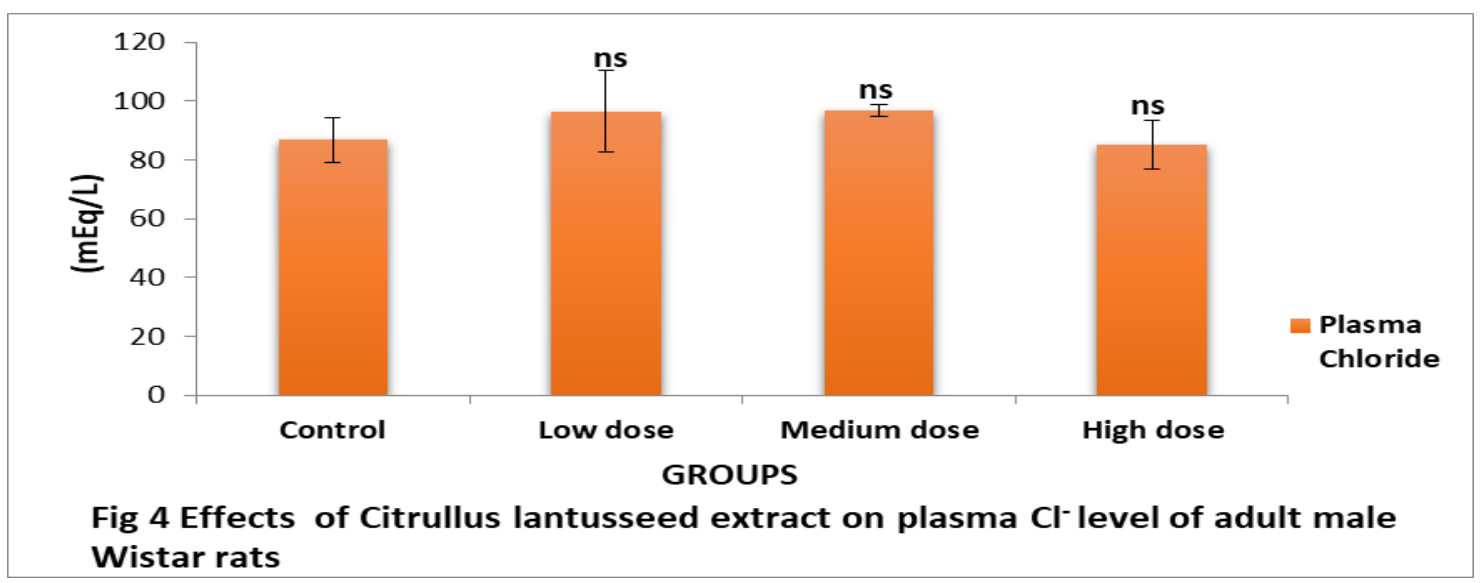

Figure 4. Effect of Citrullus lanatus seed extract on plasma chloride level of male Wistar rats.

Values are expressed as mean \pm Standard error of mean (S.E.M), $n=4$. $P>0.05^{n s}$ : No Significant, $P<0.05^{a}$ :

Significant increase when compared control group. $P<0.05^{b}$ : Significant decrease when compared control group.

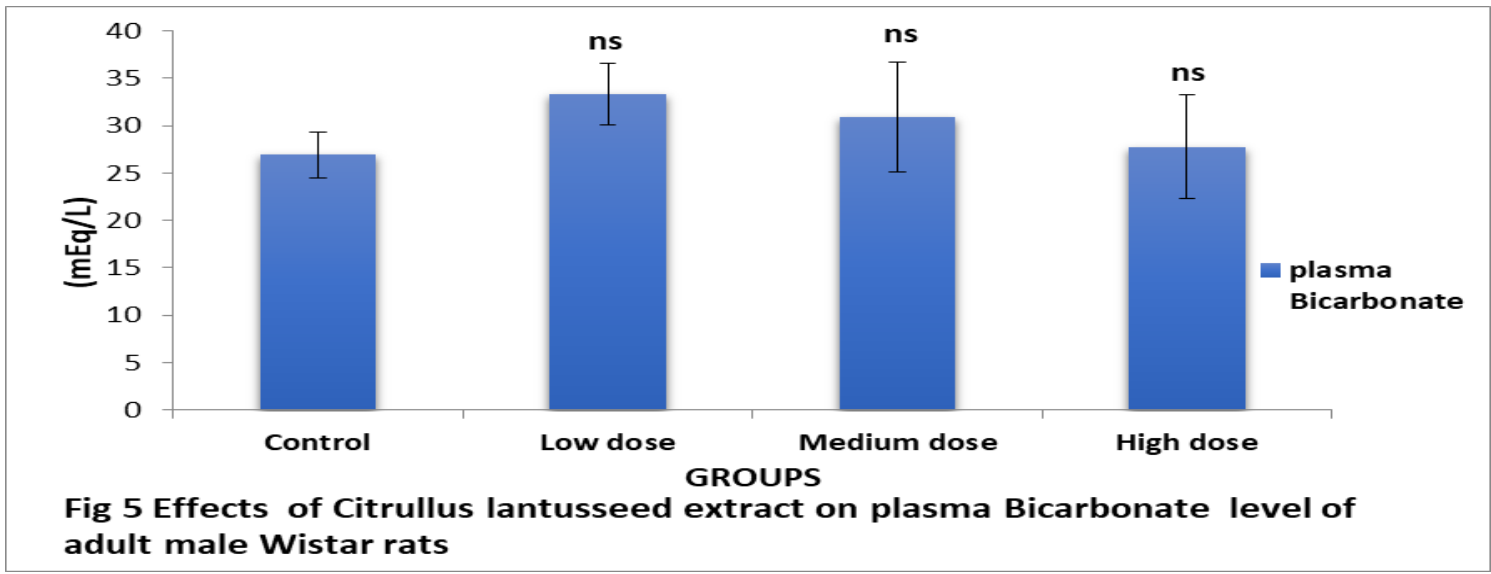

Figure 5. Effect of Citrullus lanatus seed extract on plasma bicarbonate level of male Wistar rats.

Values are expressed as mean \pm Standard error of mean (S.E.M), $n=4$. $P>0.05^{n s}$ : No Significant, $P<0.05^{a}$ :

Significant increase when compared control group. $P<0.05^{b}$ : Significant decrease when compared control group.

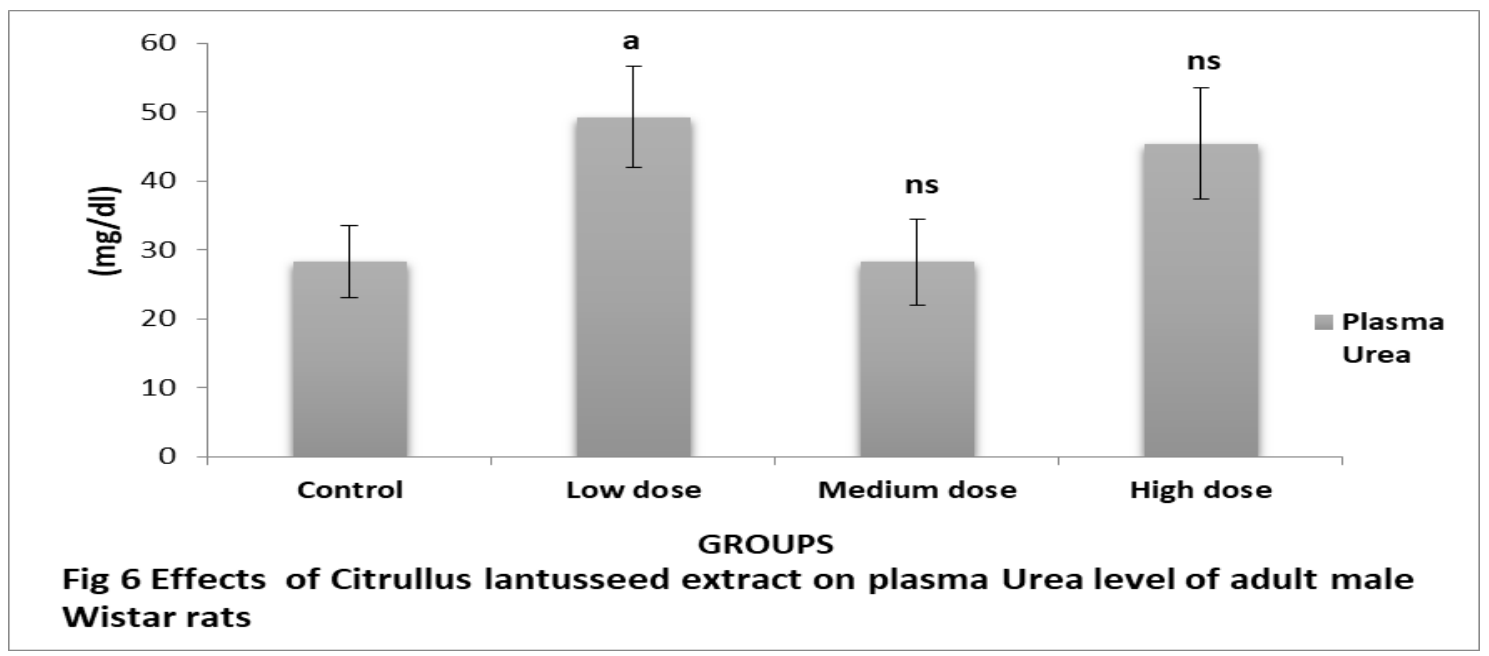

Figure 6. Effect of Citrullus lanatus seed extract on plasma urea level of male Wistar rats.

Values are expressed as mean \pm Standard error of mean (S.E.M), $n=4$. $P>0.05^{n s}$ : No Significant, $P<0.05^{a}$ : Significant increase when compared control group. $P<0.05^{b}$ : Significant increase when compared control group. 


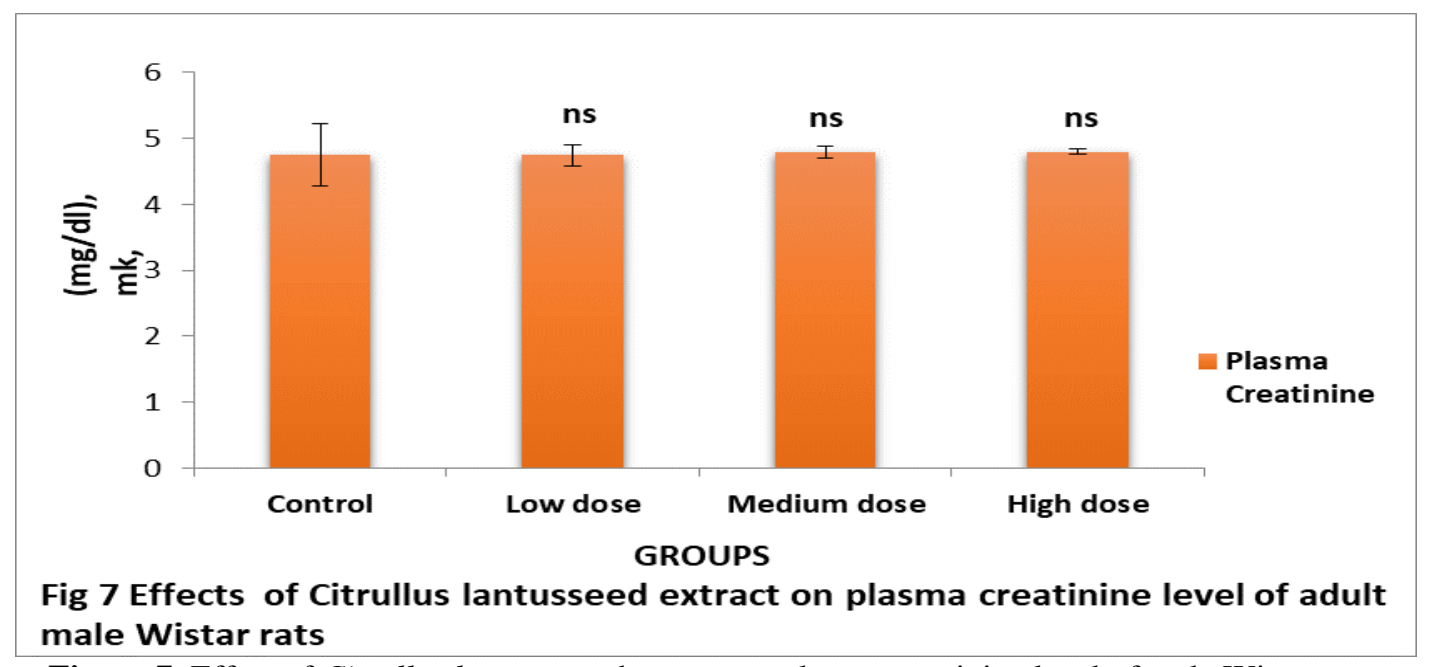

Figure 7. Effect of Citrullus lanatus seed extract on plasma creatinine level of male Wistar rats.

Values are expressed as mean \pm Standard error of mean (S.E.M), $n=4$. $P>0.05^{n s}$ : No Significant, $P>0.05^{a}$ : No Significant increase when compared with control group. $P>0.05^{b}$ : No Significant increase when compared control group.

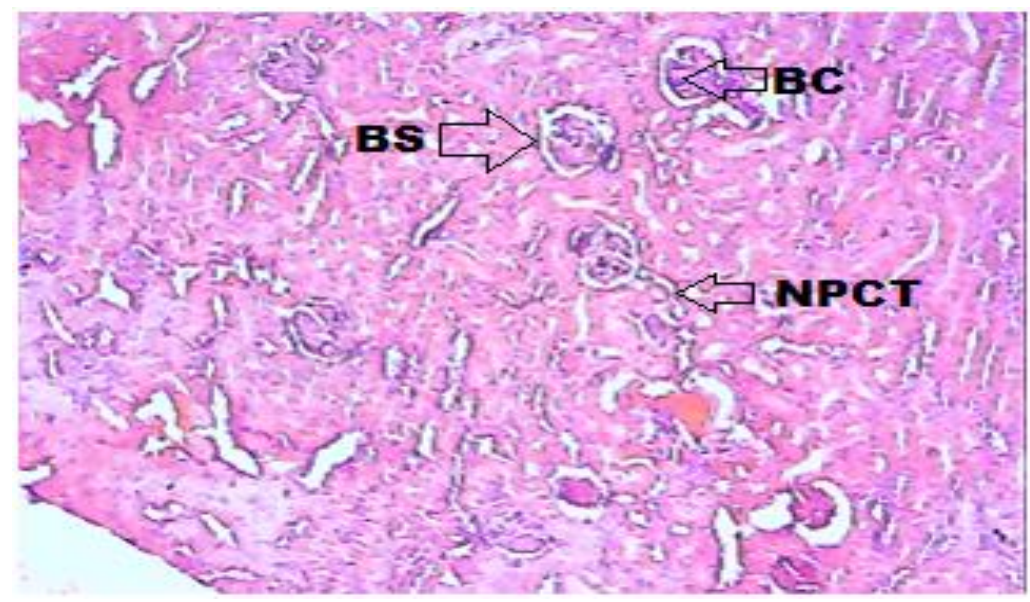

Plate A: Kidney. $\mathrm{H}$ and $\mathrm{E}$ (x 100)

Micrograph shows sections of the Bowman's capsule (BC), Bowman's space (BS) and Neck of proximal convoluted tubule (NPCT,

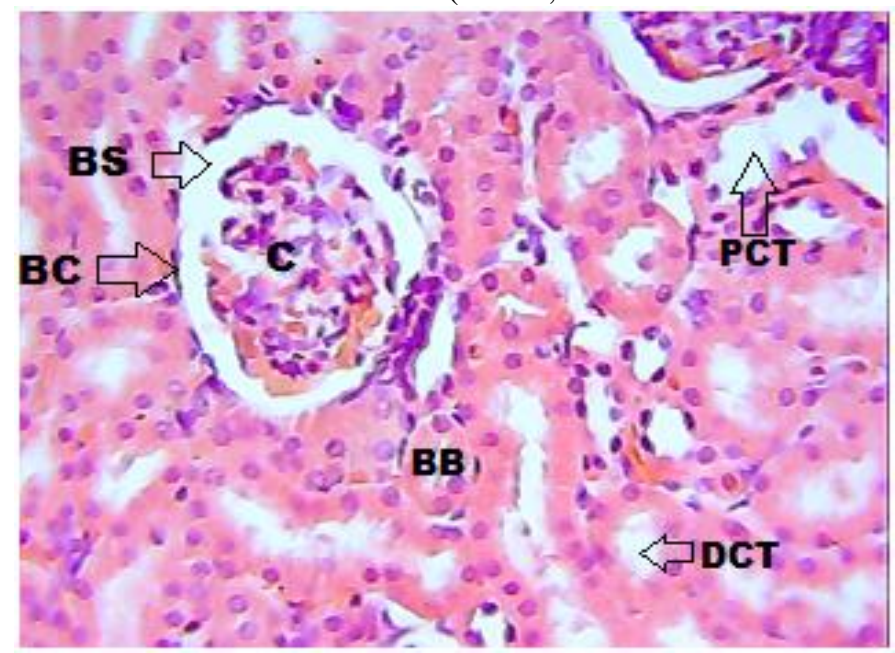

Plate B: Kidney. $H$ and E (x 400) 
Micrograph shows sections of the Bowman's capsule (BC), Bowman's space (BS), Capillaries (C), Proximal convoluted tubule (PCT), Distal convoluted tubule (DCT) and Brush border (BB).

Figure 8. Effect of Citrullus lanatus seed extract on the histology of the kidney of adult male Wistar rats

\section{DISCUSSION}

This study evaluated the effect of Citrullus lanatus seed extract on serum electrolytes and histology of the kidney in adult male Wistar rats. Findings from this study show a dose-dependent increase in bodyweight of animals given Citrullus lanatus seed extract. This is believed to be a result of the high carbohydrate and protein content of Citrullus lanatus [14].

The Sodium ion is a strategic Extracellular Fluid electrolyte that plays a diverse and important role in many physiological processes such as excitable tissues for depolarization and also relevant in neuron function and osmoregulation between cells and the extracellular fluid with its distribution mediated in all animals by $\mathrm{Na}^{+} / \mathrm{K}^{+}$-ATPase [15]. The non-significant increase in serum sodium of animals treated with watermelon may be attributed to the fact that watermelon has low sodium $\left(\mathrm{Na}^{+}\right)$ content (about $1 \mathrm{mg}(0 \%)$ ) which may have contributed to its low levels seen in the serum of the rats. This is in agreement with an earlier report by Seifter [16]. This shows watermelon has no effect in serum sodium level and thus causes no known and investigated renal damage from its administration, as it does not affect sodium homeostasis in the body. However, sodium is an important nutrient that controls blood volume, blood pressure, osmotic equilibrium and $\mathrm{pH}$. With the renin-angiotensinaldosterone system, the kidney is can regulate the amount of sodium in the body. Abnormal regulation of sodium results in hyperternatremia, hyponatremia, hypertension and renal failure as an end course.

Potassium is an essential intracellular mineral and important in maintaining fluid and electrolyte balance in the bodies of humans and animals. Abnormal regulation of potassium leads to hypokalemia. The significant increase in serum potassium level observed in this study may be because watermelon contains a higher amount of potassium when compared to sodium and this may have accounted for the elevated potassium level. This finding corroborated the report by Seifter [16], that a half cup of watermelon contains a high amount of potassium, about $112 \mathrm{mg}(2 \%)$ of the total mineral contained in the watermelon [16]. This implies that increase consumption of watermelon can lead to building up of potassium in the body, which could ultimately lead to hyperkalemia.

Findings from our current study show no remarkable difference in plasma $\mathrm{Cl}^{-}, \mathrm{HCO}_{3}{ }^{-}$ and creatinine levels when experimental animals are compared with control. The reason for this seemingly unnoticed difference between the treated and control concerning these aforementioned electrolytes is not clear. However, creatinine is a metabolic product from redox reaction of skeletal muscle [17] and might have been excreted by the kidney [18].

As was also observed in this study the elevated urea level could be attributed to the high level of protein present in the seed extract [19]. Another possible reason could be linked to the fact that Urea being a metabolic product from redox reaction of protein could be excreted by the kidney [18,19] Findings from this study shows normal histological architecture; containing a cortex with several variably sized renal capsules. The hilum of the kidney is lined by transitional epithelium. The possible reasons for this appearance are however not clear.

Conclusion. The kidney is the main regulator of electrolyte homeostasis in the body and as such, any condition that affects the renal system affects the renal clearance of these 
electrolytes in the blood. Every aspect of the fruit of watermelon has nutritional value, including the rind and the seeds. Administration of Citrullus lanatus fruit extract did not affect serum sodium, $\mathrm{Cl}^{-}$, $\mathrm{HCO}_{3}{ }^{-}$, and creatinine level of Wistar rats. However, administration of Citrullus lanatus fruit extract significantly increased serum potassium and urea level in Wistar rats. Administration of Citrullus lanatus fruit extract also increased bodyweight of Wistar rats in a dose dependent manner, which can be traced to its rich nutritional values. It is our recommendation that care should be taken in consuming watermelon as it causes increase in potassium level, which can ultimately lead to hyperkalemia.

Acknowledgement. The authors wish to appreciate our research assistant $\mathrm{Mr}$ Onyeogoh Destiny Paul for his effort in the course of data collection.

\section{REFERENCES}

1. WHO (1977). Resolution-promotion and development of training and research in traditional medicine. WHO Document No., 30: 49-49.

2. Sofowora. (1993). A. Medicinal Plants and Traditional Medicine in Africa. 2nd Ed., Spectrum Books Ltd., Ibadan, Nigeria, ISBN-13:289.

3. Iwu, M.W (1983). Traditional Igbo Medicine. Institute of African Studies University of Nigeria, Nsukka.

4. Elujoba, A.A., Odeleye, O.M. and Ogunyemi, C.M. (2005). Traditional Medical Development for medical and dental primary healthcare delivery system in Africa. African J. Traditional, Complementary and Alternative Medicine. 2(1): 46-61.

5. Robinson, R.W. and Decker-Walters Ragavan, D.S. (1997). Cucurbits. New York Cab International, pp: 226. (Crop Production Science in, Horticulture nE.6).

6. Tabiri B, Agbornohevi J. K, Wireko-Manu F. D and Ompouma E. I (2016). Watermelon seeds as food: nutrient composition, phyochemicals and antioxidant activity. International journal of nutrition and food sciences 5(2): 139-144

7. Declaration of Helsinki (1996). Guide for the care of laboratory animals ( $7^{\text {th }}$ Ed). Washington DC: Natl. Acad

8. Maruna, R.F.L. (1958). Colorimetric determination of sodium in human serum and plasma. Clinica Chimica Acta, 2: 581 .

9. Terri, A.E. and Sesin, P.G. (1958). Determination of serum potassium by using sodium tetraphenylboron. American journal of Clinical Pathology, 29: 86.

10. Skeggs, LT. and Hochstrasser, HC. (1964). Thiocyanate (colorinmetric) method of chloride estimation. Clinical Chemistry 10: 918.

11. Tobacco A. (1979). Quantitative enzymatic colorimetric determination of urea. Clin. Chem: 25, 336.

12. Heinegard, D. and Tiderstrom, G. (1973). Determination of serum creatinine by a direct colorimetric method Clin. Chem. Acta:43: 305.

13. Ward J. W and Elsea J. R. (1997). Animal case and use in drug fate and metabolism. In: Edward R. G, Jean L. H (eds). Methods and techniques, $1^{\text {st }}$ edition, New York: Markel Dekker, p 114

14. Libby, P., Schoenbeck, U., Mach, F., Selwyn, A.P. and Ganz, P. (1998). Current concepts in cardiovascular pathology: the role of LDL cholesterol in plaque rupture and stabilization. American Journal of Medicine:104: 14-18.

15. Campbell, N. (1987). Biology. Benjamin/Cummings, p. 795 .

16. Seifter, J.L. (2011). Potassium disorders. In: Goldman L. Schafer. Al. eds. Cecil medicine. $24^{\text {th }}$ ed. Philadelphia, Pa: Saunders Elsevier, Chap. 119

17. Wyss M and Kaddurah-Daouk R (2000). Creatinine and creatinine metabolism. Physiology Reviews. 80(3): 1107-1213.

18. Cheesbrough M. (2009). District laboratory practice in tropical countries, Part 1. Cambridge University Press, New York, second edition. 2009; pp. 333-340

19. USDA U. S Department of Agriculture (2002). USDA nutrient database for standard reference release. U. S Department of Agriculture, Beltsville Human Nutrition Research Centre, Beltsville Md, United States: 122 - 145 